\title{
Tracing the origin of the term "gene"
}

\author{
Theano D. Kontopoulou, Spyros G. Marketos
}

International Hippocratic Foundation of Kos, Greece

\section{INTRODUCTION}

A century has passed $(1902$ - 2002) since the Danish botanist and geneticist Wilhelm Ludwig Johannsen established the scientific term "gene". The centenary of this biological term coincides with the $50^{\text {th }}$ anniversary of the unraveling of the structure of DNA, the basic molecule of heredity.

Fifty years ago "Nature" ${ }^{1}$ hosted a one-page article outlining their discovery of the DNA molecular structure written by the American biochemist and molecular biologist James Watson and the British biophysicist and molecular biologist Francis Crick. The article was only 900 words long, but its contents helped usher in a biological revolution.

In the present paper we will trace the etymology of the term "gene", since like many biologic processes, hormone secretion and action are primarily determined by genes.

\section{The ancient roots of the scientific term "gene"}

The language of medicine is the result of its

Key words: Gene, DNA, Human Hormones, Hippocrates, Johannsen WL, de Vries H, Crick FHC, Watson JD

Address correspondence and requests for reprints to: S.G. Marketos, 20 P. Ioakim Str., 10675 Athens, Greece, Tel.: +30 210-7219534, Fax: +30 210-3642197, e-mail:sgmark@freemail.gr

Received 05-02-03, Revised 13-03-03, Accepted 20-03-03 historical development. The term "gene" ("genos" and "gonos") appeared for the first time in a text of Corpus Hippocraticum named "The Sacred Disease". Hippocrates, the father of rational medicine, strove throughout his life to dissociate medicine from magic and religion and to make it a pure science. In the aforementioned text, Hippocrates claimed that epilepsy is in no sense divine but a disease like any other. Furthermore, he stated that it is a hereditary disease. "In my opinion", he writes, "the so-called Sacred Disease (Epilepsy) is no more divine than any other; it has the same nature as other diseases and the same cause that gives rise to individual diseases. It is also curable, no less than other illnesses, unless by long lapse of time it is so ingrained as to be more powerful than the remedies that are applied. Its origin, like that of other diseases, lies in heredity ("kata genos"). For if a phlegmatic parent has a phlegmatic child, there is nothing to prevent some of the children suffering from this disease, when one or the other of the parents suffered from it; for the seed ("gonos") comes from every part of the body, healthy from the healthy parts, diseased from the diseased part" ${ }^{2}$.

\section{THE MODERN SCIENTIFIC TERM GENE}

Wilhelm Ludwig Johannsen (1857-1927), who established the scientific term gene ${ }^{3}$, was born in Copenhagen. On leaving school he became apprenticed to a pharmacist. From his work in Danish and German pharmacies, Johannsen taught himself chemistry and developed an interest in botany. In 1881 he began work in the chemistry department of the Carlsberg laboratories, investigating dormancy in seeds, tubers and buds. In 1892 he became lecturer at the Copenhagen Agricultural College. On reading 


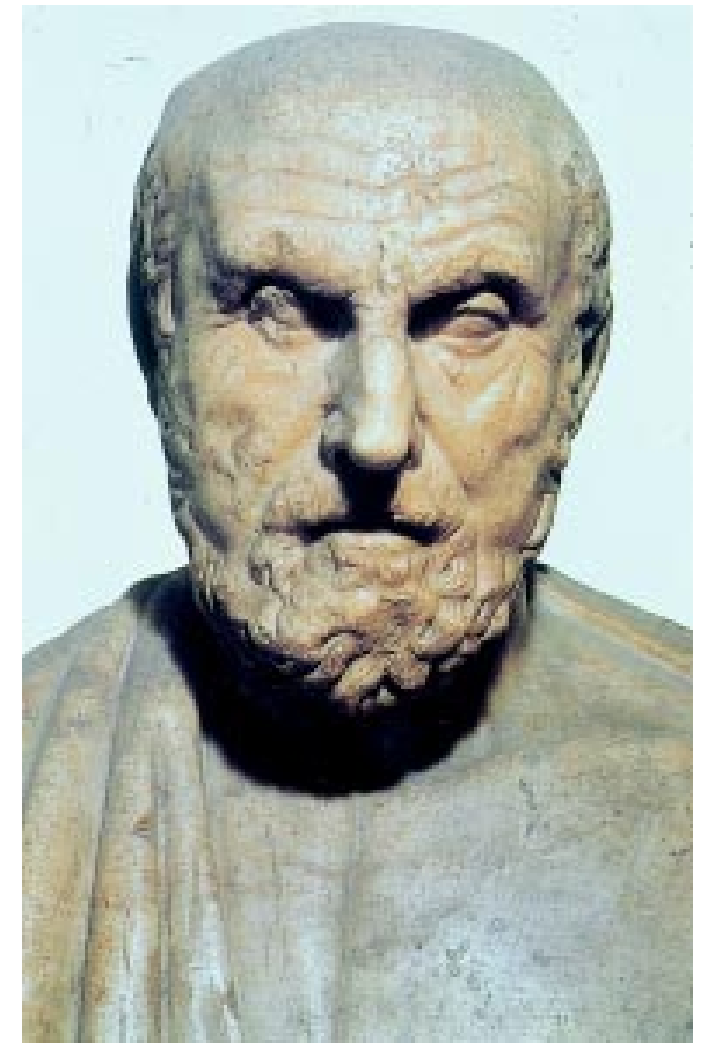

Figure 1. The first description of the term gene (genos) was made by Hippocrates the Koan.

Francis Galton's theory of heredity, he was impressed by experiments demonstrating that selection is ineffective if applied to the progeny of self-fertilizing plants. Johannsen repeated this work using the princess bean, but found that selection did work on the offspring of a mixed population of self-fertilizing beans. It was only when plants were derived from a single parent that selection had no effect. He called the descendants of a single parent a "pure line" and argued that individuals in a pure line are genetically identical: any variation among them is due to environmental effects, which are not heritable.

In 1902 Johannsen coined the terms gene, genotype, phenotype and biotype. ${ }^{4} \mathrm{He}$ lained his ideas in "On Heredity and Variation" (1896), which he revised and expanded with the rediscovery of Gregor Mendel's laws ${ }^{5,6}$ and reissued as "Elements of Heredity" (1905). The enlarged German edition of this work became available in 1909 under the title "Elemente der exakten Erblichkeitslehre", which proved one of the most influential book of its time on

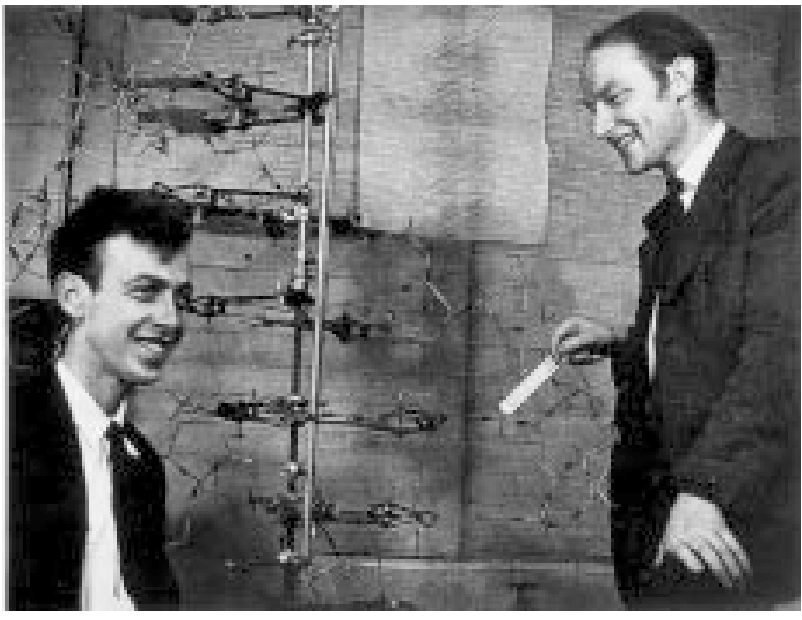

Figure 2. James Watson and Francis Crick exhibit their DNA model at Cambridge (1953).

Mendelian or classical genetics in Europe. It is obvious, therefore, that the Danish botanist was the first to use the term "gene". His Dutch coleague Hugo de Vries (1848-1935), however, deserves the credit for having recognised the unitary nature of hereditary particles which he called "pangenes",7,

\section{CONCLUSION}

The etymology of the term "gene" from the Corpus Hippocraticum represents an illustrative case showing that Greek is still a living language for international biomedicine and is invaluable as such for the universal dissemination of scientific knowledge.

\section{REFERENCES}

1. Watson JD, Crick FHC, 1953 Molecular structure of nucleic acids. Nature 171: 738-739.

2. Hippocrates 1984-1995 Loeb Classical Library. "The Sacred Disease" Harvard University Press, Cambridge, Massachusetts; pp, 150-151.

3. A Dictionary of Scientists 1999 Johannsen, Wilhelm Ludwig (1857-1927). Danish botanist and geneticist; Oxford University Press.

4. Rulliere R, 1981 Abrégé de l' Histoire de la Médecine. Masson, Paris; p, 209.

5. Mendel G, 1965 Experiments in Plant-Hybridisation. Harvard University, Cambridge, Massachussettes.

6. Sturtevant AH, 2001 A History of Genetics. Cold Spring Harbor Laboratory Press and Electronic Scholarly Publishing Project.

7. de Vries H, 1889 Intracellulare Pangenesis. Jena.

8. de Vries H, 1901 Die Mutations theorie. Leipzig. 